\title{
Maize-dominated landscapes reduce bumblebee colony growth through pollen diversity loss
}

\author{
Annika Louise Hass $^{1}$ (D) | Lara Brachmann ${ }^{1,2}$ | Péter Batáry ${ }^{1,3}$ (D) | \\ Yann Clough $^{4}$ (i) | Hermann Behling ${ }^{2}$ | Teja Tscharntke ${ }^{1}$
}

${ }^{1}$ Agroecology, University of Goettingen, Goettingen, Germany

${ }^{2}$ Department of Palynology and Climate Dynamics, Albrecht-von-Haller-Institute for Plant Sciences, University of Goettingen, Goettingen, Germany

${ }^{3}$ MTA ÖK Landscape and Conservation Ecology Research Group, Vácrátót, Hungary

${ }^{4}$ Centre for Environmental and Climate

Research, Lund University, Lund, Sweden

\section{Correspondence}

Annika Louise Hass

Email: ahass@uni-goettingen.de

Funding information

Federal Ministry of Education and Research, Grant/Award Number: FKZ: 01LC1104A

Handling Editor: Tim Diekötter

\section{Abstract}

1. Bumblebees are important pollinators for a wide range of crops and wild plants. Performance of their colonies depends on pollen and nectar as food resources, but flowering plants are scarce in modern agricultural landscapes. It is well-known that semi-natural habitats can enhance floral resources and bumblebee abundance, but the impact of different crop types and their heterogeneity at the landscape scale remains unclear.

2. We tested the effect of two different crop types (oilseed rape [OSR] and maize) and of configurational (field border density) and compositional heterogeneity (crop diversity) on weight gain of buff-tailed bumblebee colonies (Bombus terrestris) and the pollen diversity collected by them in 20 landscapes in Central Germany.

3. We found that augmenting maize cover had a detrimental effect on pollen diversity collected by bumblebees, probably due to intensive management resulting in low plant diversity. This low pollen diversity translated into reduced colony growth, since colonies with high pollen diversity gained more weight than colonies with low pollen diversity.

4. In contrast, OSR cover and configurational and compositional heterogeneity did neither affect colony growth nor pollen diversity. However, for OSR, the timing of the flowering period was important. When OSR fields had a high flower cover at the end of the OSR blooming period, colonies showed increased growth rates.

5. Synthesis and applications. Our results complement previous laboratory studies by showing that high pollen diversity leads to better colony performance under field conditions. Therefore, the maintenance of floral diversity in agricultural landscapes is crucial to ensure that bumblebees can fulfil their nutritional needs. However, the heterogeneity of crops, at least under the currently very low levels of crop rotation, does not contribute to this aim. In contrast, crop identity and timing of mass-flowering crops turned out to be important factors, as maize reduced pollen resources, while late blooming oilseed rape (OSR) was beneficial to bumblebee colonies. Hence, maize cover per landscape should be reduced and strategies to enhance landscape wide flower diversity, especially towards and after the 
end of oilseed rape bloom, should be promoted to support bumblebee colonies that provide important pollination services.

\section{KEYWORDS}

bumblebee, colony growth, configurational heterogeneity, crop diversity, landscape heterogeneity, oilseed rape, pollen diversity, pollinator

\section{1 | INTRODUCTION}

The production of many crop types depends on pollinators, with wild species being especially important and contributing to stable food production (Gallai, Salles, Settele, \& Vaissière, 2009; Garibaldi et al., 2013). Bumblebees are one important group of pollinators increasing yields of a wide range of crops, for example, apples, strawberries, tomatoes, and oilseed rape (OSR) (Bommarco, Marini, \& Vaissiere, 2012; Velthuis \& van Doorn, 2006). However, severe declines of pollinators have been observed during the last decades (Potts et al., 2010) including many bumblebee species (Goulson, Lye, \& Darvill, 2007). The drivers include habitat loss and fragmentation as well as the application of agrochemicals like insecticides and herbicides, which have led to a dramatic reduction in floral resources in modern agricultural landscapes (Goulson et al., 2007; Robinson \& Sutherland, 2002). Therefore, reducing hostility of agroecosystems is a major goal of pollinator conservation and ecological intensification to safeguard pollination services in agricultural landscapes (IPBES, 2016; Kovács-Hostyánszki et al., 2017).

Sufficient food resources are one important requirement for stable pollinator populations and bees feed exclusively on floral resources including nectar and pollen (Vaudo, Tooker, Grozinger, \& Patch, 2015). Nectar provides mainly carbohydrates giving energy for foraging flights, whereas pollen contains proteins, lipids, and micronutrients that are essential for reproduction and larvae development (Roulston \& Cane, 2000; Vaudo et al., 2015). Nutrient content of pollen differs between plant species (Roulston \& Cane, 2000), and therefore, the availability of high floral resource diversity in the landscape is expected to be essential for the persistence of bee populations (Donkersley et al., 2017; Vaudo et al., 2015). As bumblebees can discriminate between different protein concentrations by using chemo-tactile cues (Ruedenauer, Spaethe, \& Leonhardt, 2015), they optimize nutrient intake by visiting plant species to obtain certain protein to lipid ratios (Vaudo, Patch, Mortensen, Tooker, \& Grozinger, 2016). Additionally, experimental studies have shown that bees probably reduce the negative effects of unfavourable pollen types (with low nutrient content or toxic secondary plant chemicals) by mixing them with high quality pollen (Bukovinszky et al., 2017; Eckhardt, Haider, Dorn, \& Müller, 2014). Furthermore, bumblebee larvae grow larger when fed with pollen mixes compared to single pollen diets (Tasei \& Aupinel, 2008), indicating the crucial importance of the availability of floral resource diversity.

There is ample evidence that increased floral cover and diversity enhance bumblebee abundance (reviewed in Winfree, Bartomeus,
\& Cariveau, 2011). The few studies that investigated the effects of landscape-wide floral resources on bumblebee colony performance come to similar conclusions. Colonies in flower-rich suburban sites gained more weight compared to colonies in farmland (Goulson, Hughes, Derwent, \& Stout, 2002), and especially early season resources are important for colony growth (Westphal, SteffanDewenter, \& Tscharntke, 2009; Williams, Regetz, \& Kremen, 2011). However, field studies investigating whether higher pollen diversity collected by bumblebees leads to improved colony performance are rare and did not confirm the positive effects of pollen diversity indicated by laboratory results (Kämper et al., 2016).

In agricultural landscapes, the high diversity of flowering plant species growing in semi-natural habitats can improve the nutritional value of pollen collected by bees (Donkersley, Rhodes, Pickup, Jones, \& Wilson, 2014). Additionally, mass-flowering crops like OSR provide ample resources of pollen and nectar for a short time period and can therefore also enhance pollinator abundance, colony growth, and brood cell production (Holzschuh, Dormann, Tscharntke, \& Steffan-Dewenter, 2012; Westphal et al., 2009). Wind pollinated crops like maize can be an important pollen resource for honeybees (Danner, Härtel, \& Steffan-Dewenter, 2014), but wild bees have, to our knowledge, never been reported to collect maize pollen. In contrast, maize is associated with lower plant diversity than other crops inside the field and also in the adjacent boundary vegetation (Fagúndez, Olea, Tejedo, Mateo-Tomás, \& Gómez, 2016; Kleijn \& Verbeek, 2000), which might lead to reduced availability of pollen types in landscapes with high maize cover. However, the role of different crop types on wild pollinators remains unexplored and crops are usually considered as a homogeneous "hostile matrix" (Fahrig et al., 2011).

In addition to the cover of certain crop types in the landscape, higher compositional heterogeneity (higher crop diversity) and higher configurational heterogeneity (smaller field size or higher field border density) of farmland might also be beneficial to pollinators (Fahrig et al., 2015). Increased configurational heterogeneity could lead to enhanced habitat connectivity for pollinators, as they use hedgerows, grassy field margins, and potentially even the visual contrast between adjoining crops for orientation (Cranmer, McCollin, \& Ollerton, 2012; Happe et al., 2018; Hass, Kormann, et al., 2018; Van Geert, Van Rossum, \& Triest, 2010). With increasing compositional heterogeneity, there might be more diverse resources available, as different crops usually have complementary weed communities (Hyvönen \& Salonen, 2002) leading to higher pollen diversity availability in landscapes with high crop diversity. However, the effects 
of compositional and configurational heterogeneity could also be interactive because the enhanced resource availability of high crop diversity might only be accessible for pollinators if the landscape connectivity is increased by high-field border density.

Here we tested how two different crop types and the configurational and compositional heterogeneity of the crop production area at the landscape scale affect the pollen diversity collected by the colonies of Bombus terrestris and their colony performance. We focused on two major crops: First, OSR due to the provision of ample floral resources during mass flowering that affect wild bees at the local and landscape scale (Hanley et al., 2011). Second, we selected maize, because it can impact biodiversity and ecosystem services negatively (Landis, Gardiner, van der Werf, \& Swinton, 2008; Sauerbrei, Ekschmitt, Wolters, \& Gottschalk, 2014) and because its cultivation has increased by 47\% from 2004 to 2017 in Germany (Destatis, 2017) due to high bioenergy demands. In particular, we assessed evidence with respect to the following hypotheses:

1. Maize cover deteriorates colony performance through reduced pollen diversity collected by workers.

2. OSR cover at the local and landscape scale improves colony performance through greater pollen and nectar amounts collected by workers.

3. Farmland configurational heterogeneity increases colony performance directly and through higher pollen diversity collected by workers because of higher landscape connectivity and better access to diverse food resources. The positive effect of configurational heterogeneity might only be evident if compositional heterogeneity is high.

4. Farmland compositional heterogeneity increases colony performance through higher pollen diversity collected by workers, as more different crop types offer more diverse food resources. This effect might be only important if configuration is high, facilitating movement across landscapes.

\section{2 | MATERIALS AND METHODS}

\section{1 | Study sites and landscape variables}

All field experiments took place in agricultural landscapes in the surrounding of the city of Göttingen, in the state Lower Saxony of Germany (Figure 1). The hilly region is characterized by mainly intensively managed agricultural fields with cereals, OSR, maize, and sugar beet being the most commonly grown crops. We selected $201 \times 1 \mathrm{~km}$ landscapes with uncorrelated gradients of compositional and configuration heterogeneity (see Supporting Information Table S1) and from here on we will refer to the $1 \mathrm{~km}$ grids as landscapes (see Supporting Information Appendix S1 for more details on landscape selection). The minimum distance between landscapes was $1.5 \mathrm{~km}$ between centre points. Although B. terrestris individuals can travel several kilometres, the mean foraging distance is $551 \mathrm{~m}$ and the resources close to the nest are most important (Redhead et al., 2016). Therefore, we assume that the $1 \times 1 \mathrm{~km}$ grids represent a relevant spatial scale for this species.

During the field season, land use and crop types were mapped in detail for each of the selected landscapes. Furthermore, we mapped semi-natural area cover including linear and open patchy habitats. Based on these data, we calculated five landscape-scale variables for all $1 \mathrm{~km}^{2}$ landscapes (Table 1, see Supporting Information Appendix S1 for more details on landscape variable calculation).

\subsection{Field experiment and laboratory analysis}

We purchased 40 early stage $B$. terrestris colonies from a regional provider (STB Control, Germany). Each colony was delivered in a plastic box covered by cardboard. We placed the colonies in the grassy margins of the selected fields (one cereal and one OSR field per landscape) on 17-18 April 2014. As B. terrestris usually starts to produce workers at the end of March to mid-April (von Hagen \& Aichhorn, 2014), we assume that wild colonies were also in the worker production phase at these dates. Additional sugar feeders were removed, and we protected all colonies against rain by small tents made of plastic sheets (Supporting Information Figure S1). At this time, OSR was already blooming due to an unusually warm and sunny spring. To measure the colony weight, the plastic box was taken out of the cardboard box and put on a field scale. Although colonies were weighed during the day, we assume that this was a good proxy for colony growth as Westphal et al. (2009) found a high correlation of daytime weight measurements and total brood cell production. Additionally, weighing times were randomized across the landscape gradients. The first weighing took place during the colony placement in the field and all colonies had a similar initial weight $(M \pm S D$ : $634.83 \pm 29.11 \mathrm{~g})$. Afterwards, we conducted three subsequent measurements (8-9 May, 20-24 May, and 4-5 June). After the last weighing round, we collected the colonies from the field sites. Most colonies had already died at this date, but if that was not the case, the remaining bumblebees were executed by freezing.

We collected pollen samples from the experimental colonies from 13 to 21 May during warm and sunny weather conditions. Pollen samples were taken from the corbiculae of three workers of each colony. We closed the entrance hole of the colony and caught workers returning with pollen loads. Pollen loads were removed with a clean forceps and stored in an Eppendorf tube. Afterwards, the bumblebees were released. We froze the pollen samples from individual bumblebee workers until further processing. While collecting pollen samples from colonies next to OSR fields, we estimated the flower cover of this adjacent OSR field in percent cover (e.g., 30\% of the whole field were covered by OSR flowers estimated from above). This was always done by the same person to reduce bias and gave an estimate of how many resources were provided by at least one field in the landscape (due to crop variety or microclimate) at this late stage of the OSR bloom at the end of May. Therefore, we named this variable "Late flower cover OSR". From seven colonies, no pollen could be collected, because colonies were destroyed in the field by accidental mowing or died early for unknown reasons. These losses occurred randomly across the gradients of compositional and configurational heterogeneity as 

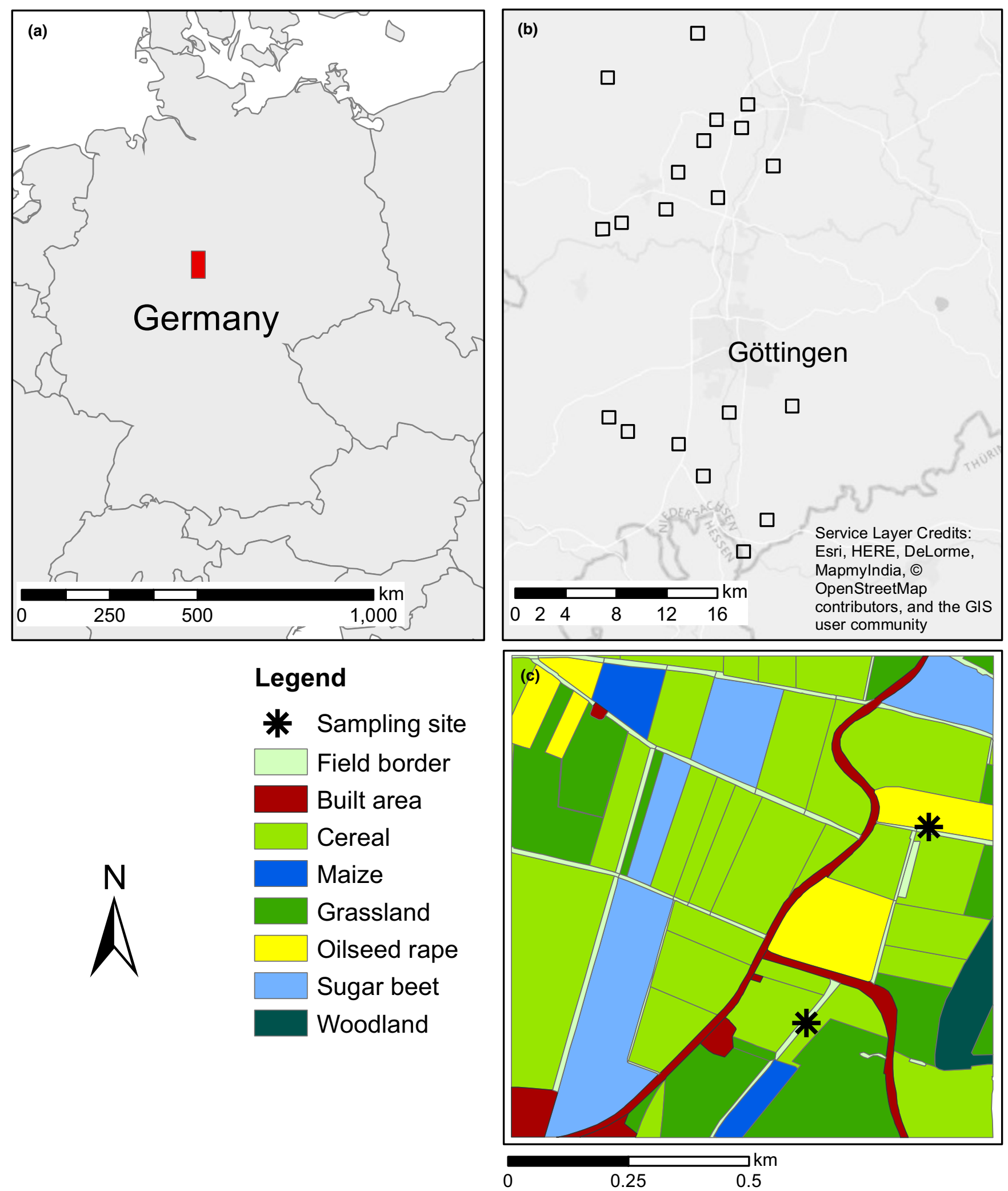

FIG URE 1 Location of (a) the study region in central Germany, (b) the $201 \times 1 \mathrm{~km}$ landscapes in the surrounding of Göttingen, and (c) one example landscape. In each landscape, all crop types and field borders were mapped and one cereal and one oilseed rape field were selected for sampling where one Bombus terrestris colony was placed in the semi-natural field boundary vegetation

well as across the gradients of OSR and maize cover in our dataset (Supporting Information Figure S2). These colonies were excluded resulting in a final dataset of 33 colonies from 19 landscapes.
To prepare pollen samples for identification, we conducted a standard acetolysis method (Faegri \& Iverson, 1989, see Supporting Information Appendix S1). For each sample, we counted and identified 500 pollen 
TAB LE 1 Variables and their measures used in the structural equation model

\begin{tabular}{|c|c|c|c|c|c|}
\hline Variable & Measure & $M$ & $S D$ & Min & Max \\
\hline \multicolumn{6}{|l|}{ Landscape scale } \\
\hline Oilseed rape (OSR) cover & Landscape crop cover (\%) & 15.30 & 9.75 & 4.41 & 41.12 \\
\hline Maize cover & Landscape crop cover (\%) & 8.13 & 11.26 & 0.00 & 46.53 \\
\hline $\begin{array}{l}\text { Farmland compositional } \\
\text { heterogeneity }\end{array}$ & $\begin{array}{l}\text { Shannon index for crop } \\
\text { diversity }\end{array}$ & 1.11 & 0.18 & 0.79 & 1.39 \\
\hline $\begin{array}{l}\text { Farmland configurational } \\
\text { heterogeneity }\end{array}$ & Field border density (m/ha) & 221.39 & 63.36 & 123.27 & 312.54 \\
\hline Semi-natural cover & Landscape cover (\%) & 7.40 & 3.27 & 2.85 & 17.87 \\
\hline \multicolumn{6}{|l|}{ Local scale } \\
\hline Local crop type & Cereal and oilseed rape fields & & & & \\
\hline Late flower cover OSR & $\begin{array}{l}\text { Oilseed rape flower cover end } \\
\text { May (\%) }\end{array}$ & 14.12 & 10.79 & 1.00 & 35.00 \\
\hline
\end{tabular}

grains. As some pollen (e.g. wind dispersed pollen grains) could have been found on the bumblebees randomly, without having been actively collected, we excluded all pollen types that were counted less than five times in a sample.

\section{3 | Data analysis}

For each colony, we calculated maximum colony weight gain, which was the difference between the first weight during placement in the field and the highest measured weight during the field experiment, which was usually the weight of the third round (20-24 May). However, four colonies reached their maximum weight already during the second round. For pollen diversity, we pooled pollen species data for the three samples per colony and then calculated the Shannon diversity index, based on the number of different pollen types found in the sample and their abundance. Maize, OSR, and semi-natural cover were logit transformed to achieve better model fit. All analyses were conducted with R (R Development Core Team, 2016).

To analyse the effects of landscape heterogeneity and different crop types on pollen diversity collected by bumblebees and the cascading effects on colony weight gain, we used structural equation modelling. Piecewise structural equation modelling makes it possible to include random effects by allowing to combine different commonly used mixed effects models (package "piecewiseSEM," Lefcheck, 2016). First, we constructed a hypothetical model (Figure 2a). We expected that configurational and compositional heterogeneity as well as OSR and maize cover at the landscape scale would affect pollen diversity. As co-variates, we added effects of local crop type (cereal or OSR), late flower cover of OSR (see above), and semi-natural cover on pollen diversity. Additionally, we included a two-way interaction of configurational and compositional heterogeneity. For colony weight gain, we expected that it would be influenced directly by pollen diversity, configurational heterogeneity, and OSR cover as well as by local crop type, late flower cover OSR, and semi-natural cover. We did not include compositional heterogeneity and maize cover in this model, because the hypothesis was that these two variables affect colony growth only indirectly through pollen diversity. We are aware that there could be direct effects of certain crops due to specific pesticide applications. However, as data for pesticide applications in our landscapes were not available, we did not include these direct pathways. As modelling all these effects in one structural equation model was not possible (d-rule: the number of samples per path should be at least 5, Grace, Scheiner, \& Schoolmaster, 2015), we first constructed two common linear mixed effects models with pollen diversity and colony weight gain as response variables including all effects mentioned above (package "nlme," Pinheiro, Bates, DebRoy, \& Sarkar, 2017). As random effects, we always included landscape comprising two sampled fields. Then, we used an automated stepwise backwards selection process based on AIC (Akaike information criterion) for both models until the best model was found. This simplification process resulted in the final SEM including six paths (Figure $2 b$ ), which is in line with the d-rule, as data from 33 colonies were included in the model. These best models included paths of compositional and configurational heterogeneity as well as their interaction and maize cover to pollen diversity and paths of pollen diversity and late flower cover to colony weight gain. To check how our simplification method affected the results, we also fit all model subsets using the "dredge" function from "MuMIn" package (Barton, 2018) and ran linear mixed effect models with all variables included in the models with $\triangle \mathrm{AICc}<2$. Then, we compared the estimates and $p$-values with those from the models of the stepwise reduction and the full models (including all variables without simplification). For all models, we checked homoscedasticity and normality of residuals as well as collinearity of included variables by variance inflation factors, because there were correlations between some of our variables (Supporting Information Table S1), but no problems were detected.

\section{3 | RESULTS}

The 33 colonies included in the analysis developed well with their maximum weight gain at the end of May (mean weight gain \pm SD: 
(a)
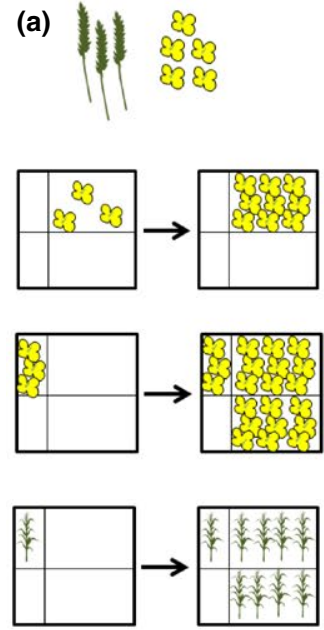

Maize cover [\%]
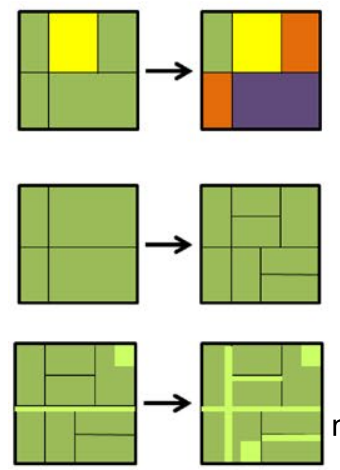

Seminatural cover [\%]

Local crop type

Late flower cover OSR [\%]

\section{Oilseed rape (OSR) cover [\%]}

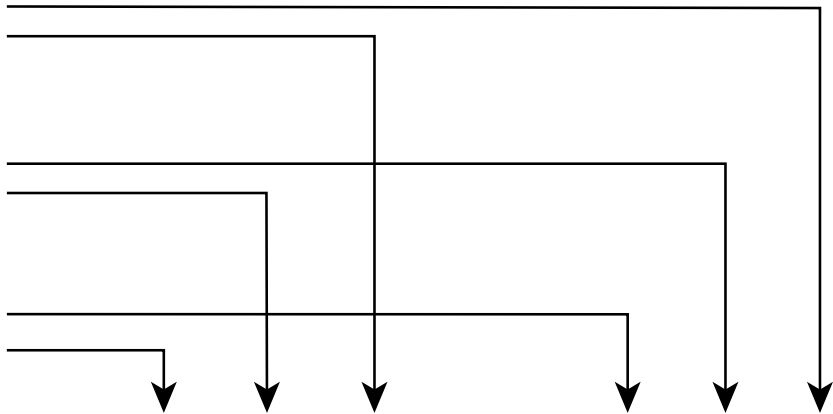

Pollen diversity

Colony weight gain
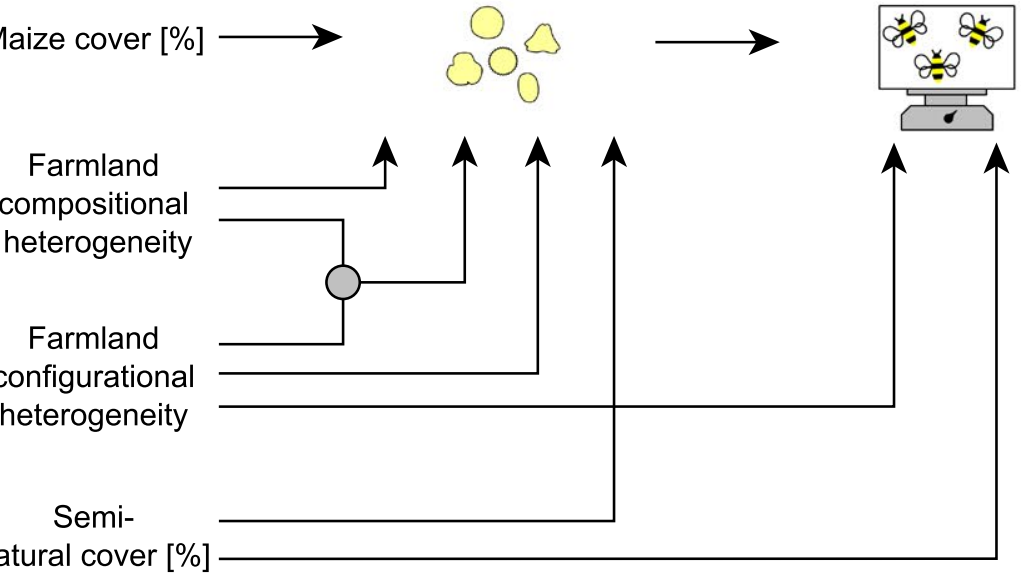

(b)

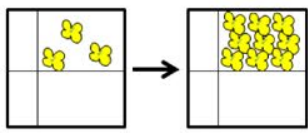

Late flower

0.47 cover OSR [\%]
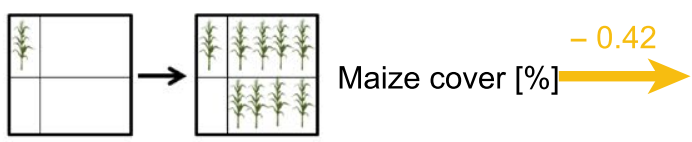

Pollen diversity
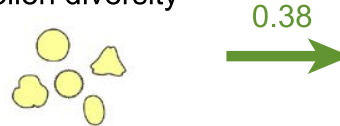

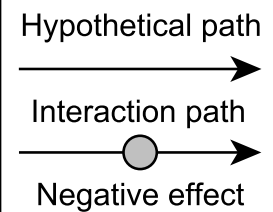

Positive effect

Non-significant
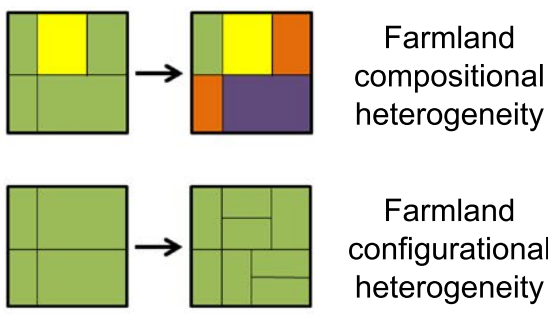

heterogeneity

FIGURE 2 Structural equation models including effects of local and landscape variables on pollen diversity collected by workers of 33 Bombus terrestris colonies and their colony performance measured as maximum weight gain after 4 weeks in the field: (a) Hypothetical model including all pathways and (b) final model including all pathways after model simplification based on AIC. Local crop type indicates whether a colony was placed next to a cereal or oilseed rape field and late flower cover oilseed rape (OSR) is the cover of flowers in oilseed rape fields during the late stage of blooming (end of May) when pollen samples were collected. Numbers next to arrows show standardized regression coefficients

$389.18 \pm 222.55 \mathrm{~g})$. From the pollen samples, we identified 19 pollen types of which few could be identified to species level and most could be assigned to a pollen type group (Table 2). The most abundant pollen type was Brassicaceae, which we expect to be all OSR due to its widespread abundance in agricultural fields and because no other frequent wild Brassicaceae species were observed in our landscapes. Other commonly collected 
pollen types were from the Sorbus group, Trifolium repens type, and Vicia type.

The best SEM identified by the model simplification based on stepwise reduction fits the data well (Fisher's $C=16.49, p=0.086$ ) and no important path was missing, indicated by non-significant independence claims. Model results are presented in Table 3. Pollen diversity was negatively affected by maize cover (Figure 3a). Additionally, colony weight gain benefited from high pollen diversity and was also positively influenced by a high flower cover of OSR in late spring (Figure $3 \mathrm{~b}, \mathrm{c}$ ). Compositional and configurational heterogeneity had no significant effect on pollen diversity collected by the colonies although included in the best model (Figure 2b). Likewise, the interaction term of compositional and configurational heterogeneity was not significant. Comparing these results to those of the full model and those of the reduced model based on $\triangle \mathrm{AICC}<2$ we found similar effects (Supporting Information Table S2). For the model with pollen diversity as response variable maize cover also had a significant effect in the full model $(p=0.042)$ and was very close to significance in the $\triangle \mathrm{AICc}<2$ model $(p=0.061)$. For the model with colony weight gain as response variable, the results from the two simplification methods and the full model were identical.

TAB LE 2 Pollen types identified from pollen loads of Bombus terrestris workers. Abundances show the number of pollen grains found across all samples and samples indicate the number of workers that were found to carry this pollen type. Pollen types with less than five grains were excluded

\begin{tabular}{|lcc|}
\hline Pollen type & Abundance & Samples \\
\hline Brassicaceae & 22,202 & 69 \\
\hline Sorbus group 1 & 12,613 & 36 \\
\hline Trifolium repens type & 6,500 & 17 \\
\hline Vicia type 1 & 2,963 & 8 \\
\hline Phacelia tanacetifolia & 618 & 2 \\
\hline Ranunculus acris type & 550 & 3 \\
\hline Sorbus group 2 & 499 & 1 \\
\hline Cimicifuga foetida & 498 & 1 \\
\hline Rosaceae & 496 & 1 \\
\hline Plantago lanceolata & 478 & 2 \\
\hline Spergularia type & 464 & 1 \\
\hline Crataegus monogyna & 316 & 1 \\
\hline Lamium album type & 313 & 2 \\
\hline Vicia type 2 & 196 & 2 \\
\hline Potentilla type & 53 & 1 \\
\hline Sambucus nigra type & 51 & 2 \\
\hline Viburnum opulus type & 18 & 2 \\
\hline Symphytum officinale & 15 & 1 \\
\hline Secale & 501 & 2 \\
\hline Unidentified & 49,349 & 1 \\
\hline Total & & 2 \\
\hline & 5018 & 2 \\
\hline
\end{tabular}

\section{4 | DISCUSSION}

In this study, we clearly demonstrate that maize cover at the landscape scale can deteriorate bumblebee colony weight gain, which appeared to be mediated by reduced pollen diversity. Additionally, colony weight gain was strongly influenced by the flower density of OSR fields at the end of May.

Our results are in accordance with previous studies showing negative effects of maize on biodiversity and ecosystem services, for example, for birds (Sauerbrei et al., 2014) and natural enemies of aphids (Landis et al., 2008). The reduced pollen diversity collected by the colonies in landscapes with high maize cover could be explained by the low plant diversity found not only inside the fields of this crop compared to cereal fields (Fagúndez et al., 2016) but also in semi-natural field boundaries adjacent to maize (Kleijn \& Verbeek, 2000). Probably, the intensive management of maize requiring high fertilizer and herbicide input is responsible for this reduced plant diversity (Fagúndez et al., 2016; Kleijn \& Verbeek, 2000).

As pollen diversity was directly related to high colony weight gain, increased pollen diversity under field conditions can be valued as highly beneficial to bumblebee colony performance. Thereby, we complement the results of laboratory studies showing positive effects of pollen diversity on pollinator offspring development (Eckhardt et al., 2014; Tasei \& Aupinel, 2008). Through increased pollen diversity, the bumblebees are possibly able to fulfil different resource requirements as different pollen species provide different nutrients that include proteins, lipids, and other micronutrients such as vitamins (Roulston \& Cane, 2000; Vaudo et al., 2015). It is also possible that mixing of different pollen types makes it possible for bumblebees to exploit more resources as pollen of low quality, which are lethal as pure diets for larvae, can be consumed without negative impact in mixtures with high-quality pollen (Bukovinszky et al., 2017; Eckhardt et al., 2014). Although the production of queens can respond differently to environmental factors than colony growth (Westphal et al., 2009; Williams et al., 2011), larger colonies usually also produce more queens (Goulson et al., 2002; Kämper et al., 2016; Westphal et al., 2009). Therefore, it may be likely that this increase in colony growth also affected reproductive success and thereby population viability of the bumblebees (Crone \& Williams, 2016). However, we only sampled pollen during a short time period and studies on bumblebee pollen diets throughout the season are necessary to complete our understanding of the effects of pollen diversity on colony performance.

An alternative explanation for the positive effect of pollen diversity could be its strong negative correlation with the proportion of OSR pollen (Supporting Information Figure S3) indicating that the bumblebees switch to other pollen resources than OSR if possible. This is in accordance with other studies showing that bumblebees and honey bees avoid OSR pollen (Kämper et al., 2016; Requier et al., 2015). One possible explanation could be that OSR pollen contains toxic secondary plant chemicals, for example, glucosinolates, an important defence against herbivores in the order Brassicale (Kämper et al., 2016; Wittstock, Kliebenstein, Lambrix, Reichelt, \& 


\begin{tabular}{|c|c|c|c|c|}
\hline & Estimate & Lower $95 \% \mathrm{Cl}$ & Upper $95 \% \mathrm{Cl}$ & $p$-value \\
\hline \multicolumn{5}{|c|}{ (a) Model 1: Response pollen diversity } \\
\hline Intercept & 0.04 & -0.27 & 0.35 & 0.808 \\
\hline Maize & -0.42 & -0.77 & -0.07 & 0.034 \\
\hline Field border density & -0.29 & -0.61 & 0.03 & 0.096 \\
\hline Crop diversity & 0.08 & -0.28 & 0.45 & 0.667 \\
\hline $\begin{array}{l}\text { Field border density : } \\
\text { crop diversity }\end{array}$ & -0.32 & -0.75 & 0.11 & 0.171 \\
\hline \multicolumn{5}{|c|}{ (b) Model 2: Response colony weight gain } \\
\hline Intercept & 0.00 & -0.30 & 0.29 & 0.978 \\
\hline Pollen diversity & 0.38 & 0.10 & 0.66 & 0.021 \\
\hline Late flower cover OSR & 0.47 & 0.17 & 0.77 & 0.007 \\
\hline
\end{tabular}

TAB LE 3 Model results for the two models used in the structural equation model: (a) with pollen diversity and (b) with maximum weight gain of bumblebee colonies as response variables

$\mathrm{Cl}$ : confidence interval.

(a)

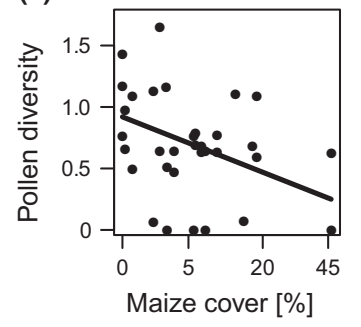

(b)

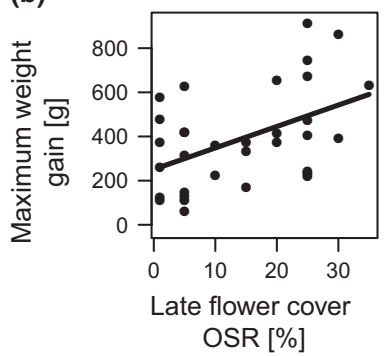

(c)

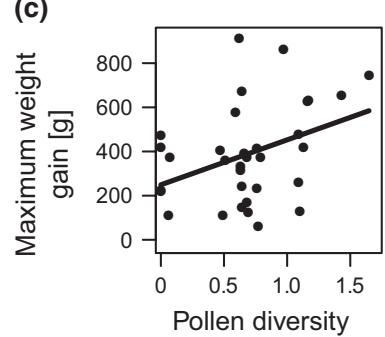

FIGURE 3 Effects of (a) maize cover at the landscape scale on pollen diversity (Shannon diversity index) collected by three workers of each colony, (b) late flower cover of oilseed rape (OSR) on maximum weight gain of bumblebee colonies, and (c) pollen diversity (Shannon diversity index) on maximum weight gain of 33 Bombus terrestris colonies. Lines show predictions of linear mixed effect models used in the structural equation model in Figure $2 b$

Gershenzon, 2003). Additionally, OSR seeds were frequently treated with pesticides including neonicotinoids in our study area, which might have impacted colony growth negatively (Rundlöf et al., 2015; Woodcock et al., 2017). The EU moratorium of neonicotinoids was applicable since December 2013 and did therefore not affect winter OSR sown before that date in 2013 and flowering in the fields in 2014. Additionally, OSR cover at the landscape scale did neither influence pollen diversity nor colony growth, contrasting to our expectations and the findings by Westphal et al. (2009). The reason could be that distance to the next OSR field is more important than its landscape cover, as all our colonies had at least one OSR field in the close surrounding due to the study design. However, OSR fields in our region differed in their phenology, possibly due to different varieties and local microclimate. If OSR fields provided high flower densities at the end of the OSR blooming period, the maximum weight gain of the colonies strongly increased. As this late flowering cover of OSR directly affected colony performance, but not indirectly via pollen diversity, it is likely that rather nectar than pollen resources were responsible for this impact. Indeed, OSR is much more frequently used for nectar than for pollen resources by honeybees (Requier et al., 2015), and the end of the OSR blooming period was the time when our colonies reached their maximum weight with high flight activity and possibly high nectar requirements. However, OSR fields flowering early compared to other fields might also be important for emerging queens during the nest foundation stage, which we did not investigate by placing already established colonies in our landscapes. Nevertheless, the timing of OSR field blooming seems to be an important and hitherto neglected factor that should be addressed in future studies.

Neither the compositional nor the configurational heterogeneity of the crops in our landscapes had an effect on pollen collection or colony growth of B. terrestris colonies. For configurational heterogeneity, this result is in accordance with previous studies on pollinators, which investigated the number of patches, edge length, or interpatch connectivity of semi-natural habitats per landscape and found no or only weak effects (Kennedy et al., 2013; Steckel et al., 2014). The reason might be that $B$. terrestris is a highly mobile generalist that is little affected by habitat fragmentation, which is supported by the fact that there is no strong genetic differentiation between populations in Europe (Estoup, Solignac, Cornuet, Goudet, \& Scholl, 1996), and therefore, this species might only respond to increased high quality habitat area (Carvell et al., 2017). However, this might be different for rare bumblebees (Goulson et al., 2007) or other less mobile pollinator species that could be more sensitive to 
configurational heterogeneity. For compositional heterogeneity, it is probably more important which crops are grown than how diverse the crop fields are at the landscape scale. This should be at least the case if this diversification does not include more extensively managed crops such as temporary clover/grass leys (Le Féon et al., 2013).

\section{5 | CONCLUSIONS}

We conclude that the consideration of the crop production area should be an important part of agricultural landscape management and applied pollinator research. Our results show that high maize cover can imperil pollen diversity collected by $B$. terrestris colonies translating into reduced colony performance. Thus, the expansion of this crop by $47 \%$ from 2004 to 2017 in Germany, although having reached a plateau since 2011 (Destatis, 2017), is alarming. Therefore, maize cover should be reduced or strategies should be developed to minimize the negative impact on plant and pollen diversity, for example, by establishing perennial flower strips and patches offering diverse floral resources for pollinators (Haaland, Naisbit, \& Bersier, 2011). German law requires that, in $2050,80 \%$ of the electricity should come from renewable energy sources including biomass (EEG, 2016). Our results indicate that achieving this target by expanding the area of cultivated maize could impair pollinators and possibly also pollination services. Mass-flowering crops such as OSR can increase pollinator abundance, diversity, and colony performance (Diekötter, Peter, Jauker, Wolters, \& Jauker, 2014; Holzschuh et al., 2012; Westphal et al., 2009). However, our study indicates that temporal aspects are more important than spatial cover.

We demonstrate that high pollen diversity collected by bumblebee workers is essential for colony performance under field conditions complementing previous laboratory studies (Eckhardt et al., 2014; Tasei \& Aupinel, 2008). Thereby, we support the call for boosting floral diversity in agricultural landscapes to ensure that pollinators can fulfil their nutritional requirements (Vaudo et al., 2015). High floral cover and diversity should therefore be in the focus of future landscape management and agri-environment schemes (Batáry, Dicks, Kleijn, \& Sutherland, 2015). In contrast, the compositional and configurational heterogeneity of crops at the landscape scale seems to be of minor importance, at least for the generalist $B$. terrestris, but can make a difference for other wild bee species (Hass, Kormann, et al., 2018).

\section{ACKNOWLEDGEMENTS}

This research was funded by the Federal Ministry of Education and Research in Germany, as part of the Biodiversa-Project FarmLand (FKZ: 01LC1104A). We thank all farmers who gave access to their fields and two anonymous reviewers for insightful comments. Additionally, we are grateful to Kelsey Joustra for field assistance and to Aliette Bosem Baillod for joint landscape selection and critical evaluation of an earlier version of the manuscript.

\section{AUTHORS' CONTRIBUTIONS}

A.L.H., P.B., Y.C., and T.T. conceived the ideas and designed the methodology. A.L.H. collected data and L.B. and H.B. identified pollen types. A.L.H. analysed the data and drafted the manuscript. All authors commented on the manuscript.

\section{DATA ACCESSIBILITY}

Data available from the Dryad Digital Repository https://doi. org/10.5061/dryad.1c8h2kj (Hass, Brachmann, et al., 2018).

\section{ORCID}

Annika Louise Hass (iD http://orcid.org/0000-0002-3377-4622

Péter Batáry iD http://orcid.org/0000-0002-1017-6996

Yann Clough iD http://orcid.org/0000-0002-2901-7602

\section{REFERENCES}

Barton, K. (2018). MuMIn: Multi-model interference. R package version 1.40.4. Retrieved from https://CRAN.R-project.org/package $=$ MuMIn

Batáry, P., Dicks, L. V., Kleijn, D., \& Sutherland, W. J. (2015). The role of agri-environment schemes in conservation and environmental management. Conservation Biology, 29(4), 1006-1016. https://doi. org/10.1111/cobi.12536

Bommarco, R., Marini, L., \& Vaissiere, B. E. (2012). Insect pollination enhances seed yield, quality, and market value in oilseed rape. Oecologia, 169(4), 1025-1032. https://doi.org/10.1007/ s00442-012-2271-6

Bukovinszky, T., Rikken, I., Evers, S., Wäckers, F. L., Biesmeijer, J. C., Prins, H. H. T., \& Kleijn, D. (2017). Effects of pollen species composition on the foraging behaviour and offspring performance of the mason bee Osmia bicornis (L.). Basic and Applied Ecology, 18(Suppl. C), 21-30. https://doi.org/10.1016/j.baae.2016.11.001

Carvell, C., Bourke, A. F. G., Dreier, S., Freeman, S. N., Hulmes, S., Jordan, W. C., \& Heard, M. S. (2017). Bumblebee family lineage survival is enhanced in high-quality landscapes. Nature, 543(7646), 547-549. https://doi.org/10.1038/nature21709

Cranmer, L., McCollin, D., \& Ollerton, J. (2012). Landscape structure influences pollinator movements and directly affects plant reproductive success. Oikos, 121(4), 562-568. https://doi. org/10.1111/j.1600-0706.2011.19704.x

Crone, E. E., \& Williams, N. M. (2016). Bumble bee colony dynamics: Quantifying the importance of land use and floral resources for colony growth and queen production. Ecology Letters, 19(4), 460-468. https://doi.org/10.1111/ele.12581

Danner, N., Härtel, S., \& Steffan-Dewenter, I. (2014). Maize pollen foraging by honey bees in relation to crop area and landscape context. Basic and Applied Ecology, 15(8), 677-684. https://doi.org/10.1016/j.baae.2014.08.010

Destatis. (2017). Fachserie. 3, Land- und Forstwirtschaft, Fischerei. 3 , Landwirtschaftliche Bodennutzung und pflanzliche Erzeugung. 1, Landwirtschaftliche Bodennutzung. 2, Anbau auf dem Ackerland. Vorbericht. Statistisches Bundesamt. Retrieved from https://www. destatis.de/GPStatistik/receive/DESerie_serie_00000309

Diekötter, T., Peter, F., Jauker, B., Wolters, V., \& Jauker, F. (2014). Massflowering crops increase richness of cavity-nesting bees and wasps in modern agro-ecosystems. GCB Bioenergy, 6(3), 219-226. https:// doi.org/10.1111/gcbb.12080 
Donkersley, P., Rhodes, G., Pickup, R. W., Jones, K. C., Power, E. F., Wright, G. A., \& Wilson, K. (2017). Nutritional composition of honey bee food stores vary with floral composition. Oecologia, 185(4), 749761. https://doi.org/10.1007/s00442-017-3968-3

Donkersley, P., Rhodes, G., Pickup, R. W., Jones, K. C., \& Wilson, K. (2014). Honeybee nutrition is linked to landscape composition. Ecology and Evolution, 4(21), 4195-4206. https://doi.org/10.1002/ece3.1293

Eckhardt, M., Haider, M., Dorn, S., \& Müller, A. (2014). Pollen mixing in pollen generalist solitary bees: A possible strategy to complement or mitigate unfavourable pollen properties? Journal of Animal Ecology, 83, 588-597. https://doi.org/10.1111/1365-2656.12168

EEG. (2016). Gesetz zur Einführung von Ausschreibungen für Strom aus erneuerbaren Energien und zu weiteren Änderungen des Rechts der erneuerbaren Energien. Bundesgesetzblatt Teil I, 49, 2258-2357.

Estoup, A., Solignac, M., Cornuet, J. M., Goudet, J., \& Scholl, A. (1996). Genetic differentiation of continental and island populations of Bombus terrestris (Hymenoptera: Apidae) in Europe. Molecular Ecology, 5(1), 19-31. https://doi.org/10.1111/j.1365-294X.1996. tb00288.x

Faegri, K., \& Iverson, J. (1989). Textbook of pollen analysis (4th ed.). Chichester, UK: Wiley.

Fagúndez, J., Olea, P. P., Tejedo, P., Mateo-Tomás, P., \& Gómez, D. (2016). Irrigation and maize cultivation erode plant diversity within crops in Mediterranean dry cereal agro-ecosystems. Environmental Management, 58(1), 164-174. https://doi.org/10.1007/ s00267-016-0691-5

Fahrig, L., Baudry, J., Brotons, L., Burel, F. G., Crist, T. O., Fuller, R. J., \& Martin, J.-L. (2011). Functional landscape heterogeneity and animal biodiversity in agricultural landscapes. Ecology Letters, 14(2), 101112. https://doi.org/10.1111/j.1461-0248.2010.01559.x

Fahrig, L., Girard, J., Duro, D., Pasher, J., Smith, A., Javorek, S., \& Tischendorf, L. (2015). Farmlands with smaller crop fields have higher within-field biodiversity. Agriculture, Ecosystems \& Environment, 200, 219-234. https://doi.org/10.1016/j.agee.2014.11.018

Gallai, N., Salles, J.-M., Settele, J., \& Vaissière, B. E. (2009). Economic valuation of the vulnerability of world agriculture confronted with pollinator decline. Ecological Economics, 68(3), 810-821. https://doi. org/10.1016/j.ecolecon.2008.06.014

Garibaldi, L. A., Steffan-Dewenter, I., Winfree, R., Aizen, M. A., Bommarco, R., Cunningham, S. A., \& Klein, A. M. (2013). Wild pollinators enhance fruit set of crops regardless of honey bee abundance. Science, 339(6127), 1608-1611. https://doi. org/10.1126/science.1230200

Goulson, D., Hughes, W., Derwent, L., \& Stout, J. (2002). Colony growth of the bumblebee, Bombus terrestris, in improved and conventional agricultural and suburban habitats. Oecologia, 130(2), 267-273. https://doi.org/10.1007/s004420100803

Goulson, D., Lye, G. C., \& Darvill, B. (2007). Decline and conservation of bumble bees. Annual Review of Entomology, 53(1), 191-208. https:// doi.org/10.1146/annurev.ento.53.103106.093454

Grace, J. B., Scheiner, S. M., \& Schoolmaster, D. R. (2015). Structural equation modeling: Building and evaluating causal models. In G. A. Fox, S. Negrete-Yanlelevich, \& V. J. Sosa (Eds.), Ecological statistics: From principles to applications. New York, NY: Cambridge University Press.

Haaland, C., Naisbit, R. E., \& Bersier, L.-F. (2011). Sown wildflower strips for insect conservation: A review. Insect Conservation and Diversity, 4(1), 60-80. https://doi.org/10.1111/j.1752-4598.2010.00098.x

von Hagen, E., \& Aichhorn, A. (2014). Hummeln: Bestimmen, ansiedeln, vermehren, schützen (6th ed.). Nottuln, Germany: Fauna.

Hanley, M. E., Franco, M., Dean, C. E., Franklin, E. L., Harris, H. R., Haynes, A. G., \& Knight, M. E. (2011). Increased bumblebee abundance along the margins of a mass flowering crop: Evidence for pollinator spill-over. Oikos, 120(11), 1618-1624. https://doi. org/10.1111/j.1600-0706.2011.19233.x
Happe, A.-K., Riesch, F., Rösch, V., Gallé, R., Tscharntke, T., \& Batáry, P. (2018). Small-scale agricultural landscapes and organic management support wild bee communities of cereal field boundaries. Agriculture, Ecosystems \& Environment, 254, 92-98. https://doi.org/10.1016/j. agee.2017.11.019

Hass, A. L., Brachmann, L., Batáry, P., Clough, Y., Behling, H., \& Tscharntke, T. (2018). Data from: Maize-dominated landscapes reduce bumble bee colony growth through pollen diversity loss. Dryad Digital Repository, https://doi.org/doi:10.5061/dryad.1c8h2kj

Hass, A. L., Kormann, U. G., Tscharntke, T., Clough, Y., Baillod, A. B., Sirami, C., \& Batáry, P. (2018). Landscape configurational heterogeneity by small-scale agriculture, not crop diversity, maintains pollinators and plant reproduction in western Europe. Proceedings of the Royal Society B, 285(1872), 20172242. https://doi.org/10.1098/ rspb.2017.2242

Holzschuh, A., Dormann, C. F., Tscharntke, T., \& Steffan-Dewenter, I. (2012). Mass-flowering crops enhance wild bee abundance. Oecologia, 172(2), 477-484. https://doi.org/10.1007/s00442-012-2515-5

Hyvönen, T., \& Salonen, J. (2002). Weed species diversity and community composition in cropping practices at two intensity levels - A six-year experiment. Plant Ecology, 159(1), 73-81. https://doi. org/10.1023/A:1015580722191

IPBES. (2016). The assessment report of the intergovernmental science - Policy platform on biodiversity and ecosystem services on pollinators, pollination and food production. In S. G. Potts, V. L. ImperatrizFonseca \& H. T. Ngo (Eds.), Secretariat of the intergovernmental science-policy platform on biodiversity and ecosystem services. Bonn, Germany: Author.

Kämper, W., Werner, P. K., Hilpert, A., Westphal, C., Blüthgen, N., Eltz, T., \& Leonhardt, S. D. (2016). How landscape, pollen intake and pollen quality affect colony growth in Bombus terrestris. Landscape Ecology, 31(10), 2245-2258. https://doi.org/10.1007/ s10980-016-0395-5

Kennedy, C. M., Lonsdorf, E., Neel, M. C., Williams, N. M., Ricketts, T. H., Winfree, R., \& Kremen, C. (2013). A global quantitative synthesis of local and landscape effects on wild bee pollinators in agroecosystems. Ecology Letters, 16(5), 584-599. https://doi.org/10.1111/ ele.12082

Kleijn, D., \& Verbeek, M. (2000). Factors affecting the species composition of arable field boundary vegetation. Journal of Applied Ecology, 37(2), 256-266. https://doi. org/10.1046/j.1365-2664.2000.00486.x

Kovács-Hostyánszki, A., Espíndola, A., Vanbergen, A. J., Settele, J., Kremen, C., \& Dicks, L. V. (2017). Ecological intensification to mitigate impacts of conventional intensive land use on pollinators and pollination. Ecology Letters, 20(5), 673-689. https://doi.org/10.1111/ ele.12762

Landis, D. A., Gardiner, M. M., van der Werf, W., \& Swinton, S. M. (2008). Increasing corn for biofuel production reduces biocontrol services in agricultural landscapes. Proceedings of the National Academy of Sciences of the United States of America, 105(51), 20552-20557. https://doi.org/10.1073/pnas.0804951106

Le Féon, V., Burel, F., Chifflet, R., Henry, M., Ricroch, A., Vaissière, B. E., \& Baudry, J. (2013). Solitary bee abundance and species richness in dynamic agricultural landscapes. Agriculture, Ecosystems \& Environment, 166, 94-101. https://doi.org/10.1016/j.agee.2011.06.020

Lefcheck, J. S. (2016). piecewiseSEM: Piecewise structural equation modelling in $r$ for ecology, evolution, and systematics. Methods in Ecology and Evolution, 7(5), 573-579. https://doi. org/10.1111/2041-210X.12512

Pinheiro, J., Bates, D., DebRoy, S., \& Sarkar, D.; R Development Core Team. (2017). Nlme: Linear and nonlinear mixed effects models. R package version 3.1-117.

Potts, S. G., Biesmeijer, J. C., Kremen, C., Neumann, P., Schweiger, O., \& Kunin, W. E. (2010). Global pollinator declines: Trends, impacts and 
drivers. Trends in Ecology \& Evolution, 25(6), 345-353. https://doi. org/10.1016/j.tree.2010.01.007

R Development Core Team. (2016). R: A language and environment for statistical computing. Vienna, Austria: R Foundation for Statistical Computing. Retrieved from: http://www.R-project.org/

Redhead, J. W., Dreier, S., Bourke, A. F. G., Heard, M. S., Jordan, W. C., Sumner, S., \& Carvell, C. (2016). Effects of habitat composition and landscape structure on worker foraging distances of five bumble bee species. Ecological Applications, 26(3), 726-739. https://doi. org/10.1890/15-0546

Requier, F., Odoux, J.-F., Tamic, T., Moreau, N., Henry, M., Decourtye, A., \& Bretagnolle, V. (2015). Honey bee diet in intensive farmland habitats reveals an unexpectedly high flower richness and a major role of weeds. Ecological Applications, 25(4), 881-890. https://doi. org/10.1890/14-1011.1

Robinson, R. A., \& Sutherland, W. J. (2002). Post-war changes in arable farming and biodiversity in Great Britain. Journal of Applied Ecology, 39(1), 157-176. https://doi. org/10.1046/j.1365-2664.2002.00695.x

Roulston, T. H., \& Cane, J. H. (2000). Pollen nutritional content and digestibility for animals. Plant Systematics and Evolution, 222(1-4), 187209. https://doi.org/10.1007/BF00984102

Ruedenauer, F. A., Spaethe, J., \& Leonhardt, S. D. (2015). How to know which food is good for you: Bumblebees use taste to discriminate between different concentrations of food differing in nutrient content. Journal of Experimental Biology, 218(14), 2233-2240. https://doi. org/10.1242/jeb.118554

Rundlöf, M., Andersson, G. K. S., Bommarco, R., Fries, I., Hederström, V., Herbertsson, L., \& Smith, H. G. (2015). Seed coating with a neonicotinoid insecticide negatively affects wild bees. Nature, 521(7550), 77-80. https://doi.org/10.1038/nature14420

Sauerbrei, R., Ekschmitt, K., Wolters, V., \& Gottschalk, T. K. (2014). Increased energy maize production reduces farmland bird diversity. GCB Bioenergy, 6(3), 265-274. https://doi.org/10.1111/gcbb.12146

Steckel, J., Westphal, C., Peters, M. K., Bellach, M., Rothenwoehrer, C., Erasmi, S., \& Steffan-Dewenter, I. (2014). Landscape composition and configuration differently affect trap-nesting bees, wasps and their antagonists. Biological Conservation, 172, 56-64. https://doi. org/10.1016/j.biocon.2014.02.015

Tasei, J.-N., \& Aupinel, P. (2008). Nutritive value of 15 single pollens and pollen mixes tested on larvae produced by bumblebee workers (Bombus terrestris, Hymenoptera: Apidae). Apidologie, 39(4), 397-409. https://doi.org/10.1051/apido:2008017

Van Geert, A., Van Rossum, F., \& Triest, L. (2010). Do linear landscape elements in farmland act as biological corridors for pollen dispersal? Journal of Ecology, 98(1), 178-187. https://doi. org/10.1111/j.1365-2745.2009.01600.x

Vaudo, A. D., Patch, H. M., Mortensen, D. A., Tooker, J. F., \& Grozinger, C. M. (2016). Macronutrient ratios in pollen shape bumble bee (Bombus impatiens) foraging strategies and floral preferences. Proceedings of the National Academy of Sciences of the United States of America, 113, E4035-E4042. https://doi.org/10.1073/pnas.1606101113

Vaudo, A. D., Tooker, J. F., Grozinger, C. M., \& Patch, H. M. (2015). Bee nutrition and floral resource restoration. Current Opinion in Insect Science, 10(Suppl. C), 133-141. https://doi.org/10.1016/j. cois.2015.05.008

Velthuis, H. H. W., \& van Doorn, A. (2006). A century of advances in bumblebee domestication and the economic and environmental aspects of its commercialization for pollination. Apidologie, 37(4), 421-451. https://doi.org/10.1051/apido:2006019

Westphal, C., Steffan-Dewenter, I., \& Tscharntke, T. (2009). Mass flowering oilseed rape improves early colony growth but not sexual reproduction of bumblebees. Journal of Applied Ecology, 46(1), 187-193. https://doi.org/10.1111/j.1365-2664.2008.01580.x

Williams, N. M., Regetz, J., \& Kremen, C. (2011). Landscape-scale resources promote colony growth but not reproductive performance of bumble bees. Ecology, 93(5), 1049-1058. https://doi. org/10.1890/11-1006.1

Winfree, R., Bartomeus, I., \& Cariveau, D. P. (2011). Native pollinators in anthropogenic habitats. Annual Review of Ecology, Evolution, and Systematics, 42(1), 1-22. https://doi.org/10.1146/ annurev-ecolsys-102710-145042

Wittstock, U., Kliebenstein, D. J., Lambrix, V., Reichelt, M., \& Gershenzon, J. (2003). Chapter five Glucosinolate hydrolysis and its impact on generalist and specialist insect herbivores. In J. T. Romeo (Ed.), Recent advances in phytochemistry (vol. 37, pp. 101-125). Amsterdam, the Netherlands: Elsevier. https://doi.org/10.1016/ s0079-9920(03)80020-5

Woodcock, B. A., Bullock, J. M., Shore, R. F., Heard, M. S., Pereira, M. G., Redhead, J., \& Pywell, R. F. (2017). Country-specific effects of neonicotinoid pesticides on honey bees and wild bees. Science, 356(6345), 1393-1395. https://doi.org/10.1126/science.aaa1190

\section{SUPPORTING INFORMATION}

Additional supporting information may be found online in the Supporting Information section at the end of the article.

How to cite this article: Hass AL, Brachmann L, Batáry P, Clough Y, Behling H, Tscharntke T. Maize-dominated landscapes reduce bumblebee colony growth through pollen diversity loss. J Appl Ecol. 2018;00:1-11. https://doi. org/10.1111/1365-2664.13296 